\title{
RELATION BETWEEN CHANGE MANAGEMENT AND CRISIS MANAGEMENT: SURVEY EVIDENCE
}

\author{
Mariana KUZMANOVA*, Ivaylo IVANOV** \\ *University of National and World Economy, Sofia, Bulgaria \\ **University of Forestry, Sofia, Bulgaria \\ kuzmanova_mt@abv.bg; ihivanov@abv.bg
}

\begin{abstract}
Crises are more often perceived as a common phenomenon which requires adequate managers' reaction and response. Nevertheless, changes have long become an element of standard management activity to support the long-term development of modern organizations. Organizations in the information and communications technology sector (ICT) face a number of challenges: intensive innovations, high R\&D expenditures, widespread ICT penetration in all areas of the economy and society, shorter product life cycle, increase of crisis phenomena, etc. The purpose of this publication is to present the results of an empirical survey on the practice of linking solutions in the field of change management and crisis management among organizations in the ICT sector in Bulgaria. Achieving this goal requires solving the following tasks: examining the essence of both change management and crisis management and the need to combine their decisions; analyzing respondents' opinions on their understanding of the different types of changes and crises experienced by organizations in the ICT sector in their development process as well as on the management activity of managers.
\end{abstract}

Keywords: change management, crisis management, relation, information and communications technology sector, Bulgaria

\section{Introduction}

Changes are essential to the development of modern organisations, including those who operate in the information and communications technologies sector. Some of the most important ones are those related to the revolutionary changes in machinery and technologies, the intensive use of the Internet and the rapid development of electronic business, the creation of virtual organisations and teams, building net organisations etc. Due to the new technologies modern organisations implement a variety of proactive changes and meet consumers' expectations increasingly faster and in this way aim to avoid or at least minimize the unfavourable consequences of the various crisis events they face in their day-to-day operations.

In a highly dynamic business environment there are both opportunities and a host of risks for the operations of the organization, which calls for new approaches to change management. Against this backdrop the rate at which changes occur becomes a strategic success factor which requires timely upgrade of the products and services provided and shortening their production cycles. Globalisation has become an essential element of the development of the business environment over the past years. What matters in this case is the effective management of the change process in order to take advantage of the opportunities and to avoid risks related to development by stimulating the increase of the productive 
potential based on knowledge, good experience, willingness to study and innovations [3].

Considering that, the process of forecasting crises usually involves difficulties and bears certain risks. Crises are difficult to control and as a rule they quickly spill beyond the borders of the unit where they have occurred. When resources and time are limited managers experience considerable difficulties in their attempts to rein the crisis processes that have arisen. As time passes the possibility for an adequate managerial response drastically declines and the efficient management of the relations with the stockholders' organization gains significant importance.

\section{Interrelations between changes, crises and their management}

\subsection{Specific characteristics of changes}

In its essence change is an objective occurrence connected with the manifestation of time lag. "In general, the notion of change can be identified with the transformation from one state into another (state, process, event). This means that change always has a beginning and an end which are characterized with a set of conditions and parameters (dimensions)" [14]. Therefore, change has two significant characteristics: content (change as a result) and transformational (change as process).

Changes in the organization as object of management have a number of characteristic features. In the first place, their complex and continuous nature should be pointed out, i.e. the alterations/adaptations which are carried out constantly concern different aspects of the activity of the organization (personality, groups, the organization as a whole). Secondly, they are determined by external and internal factors and it is compulsory to comply with the interests of specific people and groups. Their efficient management requires that adequate goals be formulated and appropriate methods for an alternative choice be implemented. In number of cases this poses a serious problem since as a rule the changes are related to loosely structured issues and risk and their ultimate success depends to a great extent on the expertise of the team responsible for their implementation.

A variety of changes are conducted in the organization. They can be organized in the following way: on the basis of the way they are carried out: planned change which includes activities based on a comprehensive analysis of the actions needed and the difficulties, threats and opportunities related to them; reactive change - a change which is carried out in response to the requirements of the issues, threats or opportunities that have occurred; on the basis of the speed at which it is conducted: slow change - a change which is carefully carried out, without haste, carefully considering every step that follows and the consequences; quick change - a change which happens quickly and is to a great extent radical in nature etc.

\subsection{Specific characteristics of crises in organisations}

Crises, for their part, are change processes as well as results from changes. "A common crisis can be defined as a change of balanced state towards imbalanced state or dominance of particular elements over the others." [13]. They call for urgent decisions for change as they pose a serious challenge for the managerial teams of the organisations. "Crises are no longer an aberrant, rare, random, or peripheral feature of today's society. They are built into the very fabric and fiber of modern societies." [9]. The reasons for the crisis have to be related to either inappropriate behavior of the organisations or to unforeseen change in the business environment [7]. Pearson and Clair point out the need for interdisciplinary approach to the study of crises and describe the organisational crisis as "a lowprobability, high-impact event that threatens the viability of the organization and is characterized by ambiguity of cause, effect and means of resolution, as well as by a belief that decisions must be made swiftly" [10]. 
This definition has to be considered tentatively as far as the characteristic "not very likely event" is concerned since the number of crisis situations over the past years has increased. Crisis is understandably seen as an innate stage of the life cycle of modern organisations [1]. It leads to both unfavourable and favourable consequences for the organisation [12].

Over the past years the role of crisis management related to forecasting, slowing down and mitigating crises has increased; by providing opportunities to manage the processes for overcoming crises and reducing their adverse consequences etc. S. Fink defines crisis management in the following way: "Crisis management planning for a crisis, a turning point - is the art of removing much of the risk and uncertainty to allow you to achieve more control over your own destiny." [4]. In this way the good managerial practices require the provision and successful implementation of specific crisis management mechanisms which help managers in their efforts to develop the organisations successfully. With respect to that it should be pointed out that crisis management involves four interrelated factors: prevention, preparation, response and revision [2].

\subsection{Interrelations between change management and crisis management}

In the process of harmonizing the decisions in the field of change management and crisis management we should have in mind the variety of difficulties related to achieving their goals. It is only natural that some authors formulated "seven myths" related to change management [8]. In this context we should have in mind the fact that conducting organizational changes is an extremely difficult task and in $70 \%$ of the cases change programmes are unsuccessful. Changes evoke emotions, diffidence and fear and consequently give rise to opposition which can be very difficult to overcome. Nowadays organisations develop cyclically: periods of relative stability are followed by periods of fast and radical changes. The results from the changes cannot be accurately forecast and the driving forces of change should be supported in their efforts to achieve the desired results. With respect to that it should be remembered that responsibility, flexibility and adaptability of organisations play an essential role in the process of overcoming the chaos and the crisis. A successful strategy is to start with something small and to focus efforts on that thing.

The so called threat-rigidity paradox is defined in the specialised literature. It can be observed in two types of reaction on the part of organisations: realizing the need for change and undertaking relevant actions and rigid preservation of established business practices. Based on this the organisations' response includes the following steps: organizational cognition and sensemaking, decision-making, and implementation [11].

L. Greiner's life cycle model is of interest in view of the subject matter under consideration. According to the author the organisation's life cycle is a sequence of evolutionary and revolutionary stages. The maximum length of each stage is 15 years and in the process of development of the organisation the requirements to its managerial sub-system change. L. Greiner's model includes the following stages: growth through creativity - a creative period (interrupted by a leadership crisis); growth through directive management (interrupted by a crisis in autonomy); growth through delegation (interrupted by crisis in control); growth through coordination (interrupted by a confidence crisis due to increased bureaucracy); growth through cooperation (interrupted by "organizational fatigue" crisis). Greiner does not provide an answer to the question about the specifics of the next stage of the life cycle. The model discussed shows that there are causative links between the individual stages. The individual structural levels of the organization might have reached different stages of the life cycle. On 
the other hand, it is possible that at a given moment elements typical of different stages can be preserved $[5,6]$.

In conclusion we should sum up that the activities in the field of change management and the crisis management interact and in this way possibilities for overcoming the crisis events in the organizations and for sustaining their development are sought.

\section{Results from the conducted empirical research}

Within the empirical research survey the opinion of 108 respondents has been studied. $54.6 \%$ of them work as experts; $17.6 \%$ are team managers or heads of departments; $13 \%$ have top managerial position and $14.8 \%$ have marked a different position (coordinators, critical incidents managers, lecturers etc). On the basis of the survey conducted in 2017 among representatives of organizations in the IT and communications technologies sector, the following conclusions can be drawn:

Table 1 Distribution of respondents on the basis of their understanding of change management (\%)

\begin{tabular}{|c|c|c|c|c|c|c|c|}
\hline № & Statement & 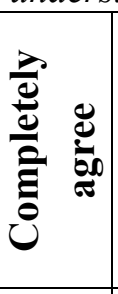 & 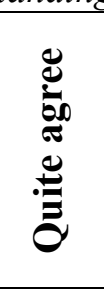 & 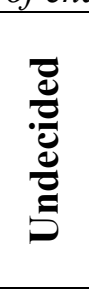 & 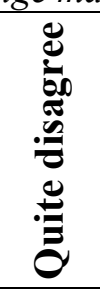 & 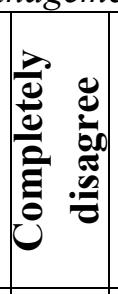 & $\stackrel{\frac{\pi}{0}}{\theta}$ \\
\hline A & The changes in the company are complex. & 28.6 & 46.7 & 15.2 & 8.6 & 1.0 & 100.0 \\
\hline B & $\begin{array}{l}\text { Changes are a source of uncertainty and fear for } \\
\text { employees.. }\end{array}$ & 15.1 & 50.9 & 6.6 & 18.9 & 8.5 & 100.0 \\
\hline $\mathrm{C}$ & $\begin{array}{l}\text { The success of changes depends to a great } \\
\text { extent on the skills of the team responsible for } \\
\text { their implementation. }\end{array}$ & 48.1 & 41.5 & 6.6 & 3.8 & & 100.0 \\
\hline $\mathrm{D}$ & $\begin{array}{l}\text { The opposition against organizational changes } \\
\text { can be reined. }\end{array}$ & 23.8 & 53.3 & 21.0 & 1.9 & & 100.0 \\
\hline $\mathrm{E}$ & Other (please, specify) & 18.2 & 18.2 & 54.5 & & 9.1 & 100.0 \\
\hline
\end{tabular}

Table 1 presents the opinion of the respondents related to change management. The respondents confirm with great certainty the statement that changes in the organisation are complex and a source of uncertainty and fear among employees. This response was given by more than $50 \%$ of all respondents. Opposition to change remains a huge problem (Only $23.8 \%$ of the respondents have replied that opposition against change can be overcome).

The majority of respondents justify the statement that the crisis relates to changes concerning the viability of the organization and calls for urgent decisions for both tactical and strategic change (98.1\%). Along with that the crisis is perceived by respondents as a phenomenon which ensues from insufficient resources and time needed for an adequate response $(78.3 \%)$. The fact that the respondents see the crisis as an opportunity for the organisation should also be taken into consideration. This opinion is held by nearly half of them (48.5\%) (See Table 2). 
Table 2 Distribution of respondents based on their understanding of organisational crisis (\%)

\begin{tabular}{|c|c|c|c|c|c|c|c|}
\hline № & Statement & 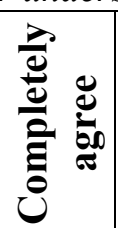 & 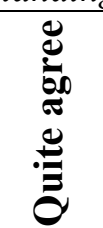 & 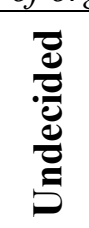 & : & 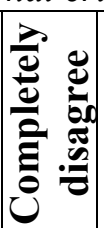 & $\stackrel{\frac{\pi}{0}}{0}$ \\
\hline A & $\begin{array}{l}\text { Changes concerning the organisation's viability } \\
\text { and call for urgent decisions for tactical and } \\
\text { strategic change. }\end{array}$ & 47.2 & 50.9 & 0.9 & & 0.9 & 100.0 \\
\hline $\mathrm{B}$ & $\begin{array}{l}\text { Related to insufficient resources and time for } \\
\text { an adequate response. }\end{array}$ & 39.6 & 38.7 & 14.2 & 7.5 & & 100.0 \\
\hline $\mathrm{C}$ & $\begin{array}{l}\text { Related to a high degree of uncertainty and risk } \\
\text { for the organization. }\end{array}$ & 45.3 & 46.2 & 4.7 & 3.8 & & 100.0 \\
\hline $\mathrm{D}$ & Opportunity for the organization & 17.1 & 31.4 & 20.0 & 21.9 & 9.5 & 100.0 \\
\hline $\mathrm{E}$ & Other (please, specify) & 50.0 & 8.3 & 41.7 & & & 100.0 \\
\hline
\end{tabular}

Table 3 Distribution of respondents based on their understanding about the peculiarities of individual crisis related to the development of the organization (\%)

\begin{tabular}{|l|l|c|c|c|c|}
\hline № & Statement & Yes & $\begin{array}{c}\text { To some } \\
\text { extent }\end{array}$ & No & Total \\
\hline A & $\begin{array}{l}\text { The 2008 financial and economic crisis had a } \\
\text { negative impact on the organization. }\end{array}$ & 43.8 & 22.5 & 100.0 \\
\hline B & $\begin{array}{l}\text { Crisis which affect primarily organisations are } \\
\text { sudden. }\end{array}$ & 16.2 & 47.5 & 36.4 & 100.0 \\
\hline C & $\begin{array}{l}\text { Crisis which affect primarily organisations are } \\
\text { gradual. }\end{array}$ & 28.9 & 40.2 & 30.9 & 100.0 \\
\hline D & Crisis are related to inefficient change management. & 33.7 & 44.9 & 21.4 & 100.0 \\
\hline E & Other (please, specify) & 83.3 & 8.3 & 8.3 & 100.0 \\
\hline
\end{tabular}

$33.8 \%$ of the respondents point out that the 2008 financial and economic crisis had a negative impact on their organisations. According to respondents the number of gradual crises exceed sudden ones: $28.9 \%$ definitely state that crises in organisations are gradual, while $16.2 \%$ - sudden. This means that there is good potential for managerial reaction in terms of timely identification of the signs of a crisis in the organization as a base for an adequate reaction. On the other hand, the statement that crisis management is in close relationship with change management is once again justified: $78.6 \%$ of the respondents state that crises in their organisations are related to inefficient change management (see Table 3 ).

It can be concluded that organisations in the information and communications technologies sector exhibit various skills related to the implementation of flexible methods for change management in the process of effective crisis decision making. Crisis should increasingly be seen as a natural phenomenon which means that managers should be familiar with them and to be capable of offering appropriate solutions so that they can quickly and successfully be dealt with.

\section{Conclusions}

It can be concluded that effective management of modern organisations calls for integrating various decisions within the entire managerial system, including the field of change management and crisis management. Organisations are large, complex and undetermined systems which increases the time necessary for making decisions whereas the time available for response is shortened due to the unstable 
and unpredictable environment. What matters in this situation is to make decisions aiming at reasonable management of the system's uncertainty. With respect to that the volume and quality of the available information are of key importance - both for the system itself and for its environment, including the adequacy of the implemented information and managerial toolkit: methods, models and system of indicators. Having considered all that an important filed for future research can be outlined: development and successful implementation of reliable quantitative and qualitative methods for forecasting organisations' behaviour and their business environment.

\section{References}

[1] Adizes, I., Managing Corporate Lifecycles. How organizations Grow, Age, and Die, Embassy Books, 2014.

[2] Coombs, W. T., Ongoing Crisis Communication: Planning, Managing, and Responding, 4th ed. Sage, Thousand Oaks, CA, 2015, as cited in Coombs, W. T., D. Laufer, Global Crisis Management - Current Research and Future Directions, Journal of International Management, 24, pp. 199-203, 2018, p. 199.

[3] Dobrovic, J., M. Lambovska, P. Gallo \& V. Timkova, Non-Financial Indicators and Their Importance in Small and Medium-Sized Enterprises, Journal of Competitiveness, 10(2), pp. 41-55, 2018.

[4] Fink, St., Crisis Management: Planning for the Inevitable, NY: Blackprint, 1986, p.15.

[5] Greiner, L. E., Evolution and Revolution as Organizations Grow, President and Fellows of Harvard College, 1972, p. 39.

[6] Greiner, L. E., Evolution and Revolution as Organizations Grow, Harvard Business Review, 1998.

[7] Hutzschenreuter, T., Unternehmenskrisen als Teil der Unternehmensentwicklung. In T. Hutzschenreuter \& T. Griess-Nega (Hrsg.), Krisenmanagement. Grundlagen, Strategien, Instrumente, (S. 3-18). Wiesbaden: Verlag Dr. Th. Gabler, 2006.

[8] Jarrett, M., The seven myths of change management, Business Strategy Review, 14 (4), 2003, pp. 22-29

[9] Mitroff, I., Anagnos, G., Managing Crises Before They Happen: What Every Execute and Manager Needs to Know about Crisis Management, N.Y.: AMACOM, American Management Association, 2001, p. 5

[10] Pearson, C., \& J. Clair, Reframing crisis management, Academy of Management Review, (23)1, pp. 59-76, 1998.

[11] Sarkar, S., O. Osiyevskyy, Organizational change and rigidity during crisis: A review of the paradox, European Management Journal, 36, pp. 47-58, 2018.

[12] Todericiu, R., E. Muscalu, A. Ghitulete, The financial crisis - an opportunity for $S M E$ 'S?, The 15th International Conference "The Knowledge-Based Organization", Economic Sciences, Conference Proceedings 3, "Nicolae Bălcescu" Land Forces Academy, pp. 170-176, Sibiu, Romania, 26-28 November, 2009.

[13] Tomastika, M., J. Strohmandlb, P. Cechc, Managerial competency of crisis managers, Procedia - Social and Behavioral Sciences, pp. 3964-3969, 174 (2015), p. 3965.

[14] Тодоров, К., Управление на организационната промяна в малките и средните фирми (МСФ), Научни трудове на УНСС 2000, С., УИ "Стопанство", с. 215-248, 2001, p. 217. 